\title{
Converts to Judaism
}

$\mathrm{T}$ he Jewish ethos sees the Jew as unique, by virtue of his being the offspring of the chosen group of people who left Egypt, stood at Mount Sinai, received God's Torah, and entered into an eternal covenant with God. This ethos constituted the foundation of the Jew's identity during the Middle Ages. The concept is expressed in the personality of the Jew and is transmitted in a direct and unmediated way to his descendants. Thus, only a Jew, himself the descendant of Jews, can recite the formula of the blessing 'Blessed are You, O Lord God, King of the Universe, who has sanctified us with His commandments and commanded us,' as a descendant of those who directly received the Torah from God, and were sanctified and commanded by Him. Only a Jew, as the descendant of Jews, can address God in prayer using the phrase 'our God and God of our fathers,' because God is indeed his God and the God of his ancestors. Similarly, he may thank God in the Blessing after Meals for giving him 'the goodly land which You promised to our forefathers,' because he is a direct descendant of those who stood at Sinai and received that promise. This approach is closely related to the attitudes examined during the course of this study, according to which the nature of the Jew is not subject to change; hence, even if he converts to Christianity and is now immersed in the impurity of the Christian religion, which is seen as tantamount to idolatry, he still remains a 'New Christian,' a Jew in essence. We have seen above how this statement, applied to an apostate, changes due to the influence of historical events. Did the attitude concerning one who joined the Jewish religion change in a similar manner? ${ }^{1}$

As soon as the proselyte joins the Jewish group, the halakhic definition found in b. Yevamot 22a applies to him: 'A proselyte who converted is like a newborn infant.' ${ }^{2}$ The proselyte is thus born anew, and all his previous family connections are completely nullified. This perception of religious 
conversion as an act of death and rebirth is known in many other societies. ${ }^{3}$ Therefore (at least in theory), a father and daughter who were converted may marry one another, the biological son of a convert does not inherit from his father, and biological relatives who converted may testify against one another in a Rabbinic Court. The halakhic logic is flawless: familial relationships are absolute only when they are within the Jewish framework. Even one who departs from Judaism and cuts himself off from it cannot sever his familial ties and remains within the ethnic family, which is part of his identity. By contrast, one who joins the ethnic family as a proselyte severs all of his previous family ties, which are nullified in an absolute way. ${ }^{4}$ Nonetheless, already during the Mishnaic period it was clear that, even if a convert is seen as being born anew as a Jew, he is a different kind of Jew in that he is unable to use those liturgical expressions indicative of the connection between the Jew in the present and the chain of his ancestors going back to Sinai. His connection to God as based upon the relationship to God of the patriarchs (which does not exist) is different from that of other Jews, which derives from the ancestral relationship. ${ }^{5}$

As against that approach, in the Jerusalem Talmud another seemingly marginal approach takes shape, stating that both Jews and converts have a common father - the patriarch Abraham. As Abraham made the substantive jump from serving idols to believing in the one God, he is considered the paradigmatic convert, and he received from God the title 'the father of many nations' (Genesis 17: 5-6). Therefore, his children, the proselytes, may recite the blessings and express themselves liturgically like all other Jews. This approach seems marginal in comparison to the direction developed in the Mishnah, which emphasizes the difference of the proselyte within Jewish society. Moreover, in the framework of the Talmudic discussion regarding those things one must tell the prospective proselyte prior to his conversion, one of the amoraim, Rav Helbo, states that 'converts are as difficult to Israel as a sore'- this, in explanation of the verse in Isaiah 14:1: 'And aliens will join them and will cleave to the house of Jacob' (b. Yevamot $47 \mathrm{~b})$. It may be that during the period of Rav Helbo, a Babylonian who immigrated to the Land of Israel during the first half of the fourth century, the proselytes indeed constituted a problem. He was evidently exposed in Palestine to the fact that, after the Roman empire became Christian, heavy punishments were imposed upon those who converted to Judaism, to the extent of being sentenced to execution. ${ }^{6}$ This aphorism continued to echo throughout the history of Judaism, and its various interpretations reflect the essentially suspicious attitude towards the newcomer. Rashi, at the end of the eleventh century, explains the term 'sore' by stating that proselytes 
cause harm to Jewish society in three different ways: First, they are not expert in the mitzvoth and lead innocent Jews astray; moreover, all of the Jews pay for their mistakes. In addition, they disturb the ideal state within the Jewish community in which 'All Israel are responsible for one another' (b. Sotah 37b), a situation prevented because converts have become mixed within Israel. ${ }^{7}$ These comments of Rashi, brought as a gloss on the words of the Talmud, reflect his opinion of the proselytes of his period, or at least the fear and suspicion regarding those converts who attempted to enter the gates of the Jewish people. The medieval sages, until the end of the twelfth century, did not modify these harsh formulations.

It is not clear how widespread the phenomenon of conversion, i.e., of Christians who wished to join the Jewish camp, was prior to the twelfth century. It may be that, until that time, joining the Jewish people was perceived as a convenient transition to a quality, prestigious group. The halakhic discussion concerning the acceptance of converts during the Middle Ages relates strictly to the motivations of the prospective proselyte; the worse the situation of the Jews, the stronger became that note emphasizing the need for purity in the convert's intentions in joining Judaism. During the course of this discussion two views took shape. The one held that it is permissible to convert even someone whose intentions have not been proven at present, as it may be assumed that in the final analysis the conversion will be 'for the sake of Heaven.' Thus, for example, a certain young woman came and wished to convert in order to marry a Jewish man. The rabbis accepted this, relying upon the precedent of those cases cited in the Talmud of people who converted out of fear, as in the time of David and Solomon, or of Mordechai and Esther, or the famous case of the man converted by Hillel. ${ }^{8}$ The second approach holds that the entire conversion depends upon proving the true intentions of the convert. Rashi emphasizes in his commentary on the Talmud that 'accepting the yoke of the commandments' is of the very essence of conversion. Likewise, in Germany at the beginning of the twelfth century, Ra'avan, and other Tosaphists in his wake, underscored that, alongside informing the potential proselyte of the commandments, one must examine whether or not his motivations are pure or whether there is some ulterior motive for the conversion - in their language, if it was 'because of some cause.' At the end of the thirteenth century Mordechai ben Hillel states that, in his opinion, one ought not accept a proselyte unless it is very clear that he wishes to join the Jewish people without any ulterior motive. However, he qualifies his words by saying: 'I have written that which seems to me to be correct; and from my teachers this measure seems [right], but do not rely 
upon my understanding. ${ }^{10}$ During the Middle Ages the rabbis interrogated potential converts thoroughly, and only if they were convinced that they were doing this in a sincere and innocent way did they convert them. Above and beyond the above-mentioned discussion, which may have been theoretical, the medieval Talmudic commentators elaborated at length upon the subjects of circumcision and immersion of proselytes; there is also extant a contemporary source describing the actual reality per se. R. Gershom bar Yaakov was a mohel (ritual circumciser) who lived in Germany during the thirteenth century and wrote a book on matters of circumcision. According to him, one must be meticulous regarding all stages of the ceremony: initially, one teaches the convert and warns him regarding the difficulties involved in Judaism and in observing its mitzvoth; thereafter he must be circumcised; following that he is immersed in water; and only then can he recite the blessing, 'Blessed art Thou ... who has sanctified us with His commandments and commanded us concerning immersion'_by which he becomes a Jew. At the immersion itself three Rabbinic sages or distinguished members of the community must be present, serving as a court whose function is to witness the final stage of the entrance into Judaism. During its course (prior to the immersion itself), they again inform him of the 'light and serious mitzvoth, and their punishments and their reward.' He must accept these upon himself, and only then is he immersed in water. Rabbi Gershom testifies to a case in Mainz in which the convert was first immersed and thereafter circumcised, and it was ruled that he must be immersed a second time - that is to say, the details of the ceremony of transition were serious and valuable. ${ }^{11}$

The most striking change in the ideological attitude towards the proselyte appears at the end of the twelfth century: a change that may be traced to the writings of R. Yitzhak ben Moshe (Or Zaru'a) in northern France and of R. Eliezer ben Yoel ha-Levi in Germany.

First, the expressions relating to proselytes are greatly moderated. The negative Talmudic expression, 'Evil after evil will befall those who accept converts ... converts are as difficult to Israel as a sore' (b. Yevamot 109 b) is explained by R. Yitzhak as referring to those who accept converts indiscriminately and without examining whether or not their intentions are sincere. He supports this perception by means of a historical-value criticism against the fathers of the nation. He states that, because of the refusal of Abraham, Isaac, and Jacob to convert Timna, she became the concubine of Eliphaz son of Esau, from whom was born Amalek, whose entire purpose was to harm Israel (b. Sanhedrin 99b). Thus, Amalek was the punishment visited upon Abraham, Isaac, and Jacob because of their refusal to accept as 
convert a woman who wished to attach herself to the people of Israel. On the other hand, he stresses the positive role played by Joshua, who accepted Rahab the harlot as a convert, by Naomi, who accepted Ruth the Moabite as a convert, and by Hillel the Elder, who accepted as proselyte the man who said 'Convert me so that I can be the High Priest' (b. Shabbat 31a). In other words, he emphasizes those cases in which people acted to accept converts and succeeded, as against those in which they rejected potential converts and failed. ${ }^{12}$ Similarly, during this period the Tosaphists greatly modified Rashi's words concerning those who convert others. The expression, 'Proselytes are as difficult to Israel as a boil' is explained as reflecting a positive perception of proselytes: in their view, converts are 'difficult for Israel' because the Torah warns in twenty-four separate places that one must not harm them or cause them pain or oppression;' because Israel is scattered about the world, and as a result many converts join their nation; and because converts are meticulous in observing the commandments and remind those who are born Jews to what extent they are not careful about the mitzvoth. ${ }^{13}$ That is, the seeming criticism of proselytes is reinterpreted in a positive direction.

Second, R. Yitzhak also changes the halakhic approach concerning the convert. He is firmly opposed to the decision of Rabbenu Tam regarding the inheritance of the proselyte. He rules that a convert who has been circumcised but, for whatever reason, was not immersed, and lived for a lengthy period of time in the home of Jews, does not render their wine non-kosher-i.e., he is no longer considered as a Gentile. He further emphasizes that, if a woman converted while pregnant and then gave birth, there is no need to immerse the infant in the mikveh for conversion, he is simply circumcised like any other Jewish infant. R. Yitzhak also rules, with great sensitivity, that if a person converted together with his mother and she later died, that he may mourn for her. This decision is opposed to halakhic logic, which strongly emphasizes that a convert is born anew, hence his previous biological connections no longer exist. ${ }^{14}$

At the end of the twelfth century in Germany, R. Eliezer ben Yoel ha-Levi (Rabya'h) heralded the change in attitude towards the convert. If, in the case of R. Yitzhak, we need to conjecture as to the reason for the change, in R. Eliezer ben Yoel ha-Levi we find the departure from previous views expressed far more clearly. R. Eliezer ben Yoel ha-Levi was deeply impressed by the quality and religious devotion of those Christians who decided to convert to Judaism. He describes with great emotion a certain proselyte, 'R. Abraham son of Abraham,' who underwent the transition from Christianity to Judaism in Speyer, then went to his own city (evidently 
Cologne), where he lived with the local Jews for a considerable period of time and learned the way of life of the Jews, the Hebrew language, and the Jewish Scriptures. When R. Eliezer saw that this convert was using a Latin Bible in order to understand the Hebrew in the Pentateuch, he explained to him that it was forbidden to learn the Torah in a language other than Hebrew. R. Abraham answered him that his 'rabbis' in Speyer, those who had converted him, taught him that this was acceptable. Thus, despite his principled misgivings, R. Eliezer ben Yoel ha-Levi came to the conclusion that he was allowed to read the Torah 'in the script of the monks,' because of the special situation in which both the Jews and the proselytes found themselves. (R. Eliezer ben Yoel ha-Levi's position was based upon the midrashic interpretation of the verse, 'It is time to act on behalf of the Lord, they have violated Your Torah'_-Psalms 119:122.) When R. Eliezer ben Yoel ha-Levi heard that the inhabitants of Würzburg did not allow R. Abraham to serve as prayer leader while staying in their city, due to the ruling in Tractate Bikkurim that a convert, rather than saying 'God of our fathers' must say 'God of the fathers of Israel' or 'God of your fathers,' he wrote that in his day it was preferable to follow the ruling in the Jerusalem Talmud, stating that a convert is like a Jew in every respect because he is considered a son of the patriarch Abraham. ${ }^{15}$

This situation needs to be understood against the background of Jewish self-perception during the medieval period. So long as the convert ameliorates his own situation by converting, or there is the possibility that he will derive some sort of benefit from doing so, the Ashkenazic authorities were hesitant to accept him, and the suspicion of him remained. This intuitive suspicion of proselytes is based upon the self-perception which sees Jews in the present as the direct descendants of the Jews who stood at Mount Sinai, enjoying direct contact with God via the Torah; against them are all those who wish to join or penetrate this exclusive group. The attitude towards proselytes began to change as the situation of the Jews became more difficult, as the number of Jews who converted to Christianity grew, and as the danger to one who converted to Judaism was also exacerbated. The Christian who joined the Jewish group lost all of his property, and even placed his very life in danger. The criterion for joining the Jewish group became the danger to life this entailed, his martyr-like behavior facilitating a new value-perception of the convert. The 'people of Israel' saw itself as a distinct, extended family, beginning with the patriarch Abraham, and continuing on via his preferred son Isaac, and Jacob, the preferred son of Isaac, to the creation of the nation with all of its tribes, the sons of Jacob, who stood at Mount Sinai at the time of making the 
eternal covenant with God. The emphasis upon the shared genealogical origin of the people of Israel, which constructs the people as a single unit deriving from its common ancient ancestors, whose direct descendants allude to them in prayer, makes it difficult to accept the proselyte. He has no common father and no common essence with other Jews, beginning with the patriarchs and taking shape at Mount Sinai. In the Middle Ages, this tension was intolerable, and therefore the patriarch Abraham was called upon to bridge it. ${ }^{16}$

Already in the chronicles depicting the death of Jews as martyrs in the First Crusade, first written at the beginning of the twelfth century, there stands out the behavior of a convert in the town of Xanten who asks the most distinguished member of the community whether he, as a proselyte, can enter Paradise after dying a martyr's death. The very posing of the question testifies to the fact that the proselyte lived with the feeling of being different from his Jewish 'brethren.' In his responsum, R. Moshe ha-Kohen marshals the words of Rav Judah from the Jerusalem Talmud, written seven hundred years earlier: 'As Abraham is the father of the proselytes, you may enter Paradise with all the righteous and with Abraham.' Note the presence of other proselytes in the list of those who died as martyrs in Cologne. Particularly interesting is the figure of Rabbi Yaakov ben Rabbi Sulam who, because his father belonged to a family that 'was not honorable,' took a proselyte as his wife. He commented to all those around him that for his entire life people had treated him with contempt, but that now he was dying a distinguished martyr's death. ${ }^{17}$

The use of the figure of Abraham in connection with proselytes is decisive on two levels: Abraham became the first 'convert' when he turned from the worship of idols to the belief in the One God. By this act he endangered his life, was thrown into the fiery furnace, and saved by God. Abraham is also the archetype of one who converts others, according to the traditional interpretation of the verse 'and the souls which he made in Haran' (Genesis 12:5), according to which the word 'souls' refers to 'the proselytes whom he converted.' ${ }^{, 18}$ It is thus that Abraham appears in midrashic and in medieval literature: as a figure who was reborn, who abandons pagan religion, and who endangered his life by the very act of conversion. Thus also are depicted those Gentiles who converted when they saw the spiritual heroism of Daniel's three companions, Hananiah, Mishael, and Azariah. Isaiah 29:24 — 'And those who err in spirit will come to understanding, and those who murmur will accept instruction' - is taken as referring to those Gentiles who are present at manifestations of the greatness of the God of Israel, join the people of Israel, and become 
'understanding' and 'accept instruction.' These include Jethro, Rahab, and the other converts to Judaism in the wake of the action of Hananiah, Mishael, and Azariah. ${ }^{19}$

The name 'son of Abraham' was given to every proselyte as his patronym, thereby designating that he had been born anew; in the Middle Ages the image of the proselyte also included the subject of martyrdom. From this stage on, whenever the threat of martyrdom appears, proselytes are able to carry their new name with pride, with the confirmation of the Jewish society around them, and they are called 'Abraham' or 'the son of Abraham.' In one of the memorial books, at least three proselytes are listed, of whom two came from the world of the Church, all of whom died as martyrs for Kiddush Hashem. In the memorial book, in the list related to the city of Weissenburg, we find:

1. Rabbi Abraham son of Abraham (our Father) from France, who was 'the head of all the barefoot ones,' who became disgusted with the images and took shelter in the shadow of the Eternal Living One, and was burned for the Unity of the Name. He evidently lived at the end of the twelfth century, and is the person mentioned in Tosafot, alongside R. Yitzhak.

2. Rabbi Abraham ben Abraham from Augsburg, who was disgusted with the god of the nations and cut off the heads of the images and trusted in the Life of the Universes, and underwent severe sufferings and was burnt for the Unification of the Name on Rosh Hodesh Kislev, which was a Friday, 'in the 25th year of the sixth millennium [i.e., 5025],' 21 November 1264.

3. Rabbi Yitzhak ben Abraham Our Father from Würzburg was burned for the Unification of the Name. ${ }^{20}$

In 1264 or 1265, a proselyte named Avraham was burned at the stake in the city of Augsburg or Weissenburg. The description of his acts corresponds to that of the patriarch Abraham as described in the midrash. Like Abraham, this convert was willing to die for his new faith and was put to death by fire by the Christians. Two liturgical poems (piyyutim) written in his honor and to commemorate his martyr's death are extant; it would appear that these poems were used on the memorial day for this proselyte martyr. The piyyut, Mah rav tuvkah ('How Great is Your Goodness'), was composed by R. Mordechai ben Hillel, the close disciple of Rabbi Meir of Rothenburg and author of the most comprehensive commentary on the Talmud of his day, who himself died as a martyr. ${ }^{21}$

The author asks God to end the period of Exile and bring the Redemption, and emphasizes how loyal the Jews are to their God, that they do not sin 
and, primarily, that they are willing to sacrifice themselves in order to demonstrate that they cannot be made to change their religion. The example he cites to prove this is that of Avraham the proselyte, and the Jewish inhabitants of the city Sinzig. He emphasizes the identity between the patriarch Abraham and Avraham the proselyte.

Avraham the proselyte is perceived here as virtually identical to Abraham himself, the first proselyte and the father of all proselytes, and he now becomes 'a sweet fragrance, a burnt-offering of service on the mountain where the Lord shall be seen' - that is, a sacrifice offered on Mount Moriah, where Abraham bound his son Isaac (Genesis 22:14), following a tradition that was established in the piyyutim from the time of the First Crusade. The city of Sinzig is Mount Moriah, and the Jews who died there for Kiddush Hashem, including the proselyte, are compared to Isaac. From the perspective of Rabbi Mordechai there is no difference between the proselyte and the Jewish martyrs. The comparison between the proselyte who chose to forego his life as a Christian and the other Jews is based upon a reconstruction of the transition of the proselyte from his life as a Christian to that as a Jew, based upon the example of Abraham in the midrash, which describes the transformation from Abraham the idolater to Abraham the Hebrew. Abraham identifies the falsehood involved in the worship of idols and discovers faith in the one God, smashes the idols, and is brought to trial before King Nimrod, who orders him to be thrust into the fire in order to prove whether his God is really the true God. Abraham enters the inferno and is miraculously saved. R. Mordechai describes the thirteenth-century proselyte Avraham, who arrived at the conclusion that Judaism was the true religion, as defining the religion from which he had come as a false and idolatrous one and, like Abraham, he 'broke the idols of Christianity.' Also like Abraham, he understands that the Christian god is 'wood and stone' - pagan, created by human beings; he was circumcised at an advanced age; and he arouses discussion when he engages in polemics with the idolaters (Christians) concerning the nature of the true God. Like Abraham, he wanders here and there in order to continue his Jewishness; and he is caught and taken to be executed by fire.

In this liturgical poem, we accompany the proselyte as he is taken to be executed, wrapped in tallit and tefillin. Prior to his death he is questioned about his faith (he may have been asked this by Church officials in the hope that he would recant and confess his sins before being executed), and he answered, 'Know to whom this tallit and these tefillin belong' - that is, the proselyte. Just before his death by fire, he paraphrases the words used by Tamar in Genesis 38:25. Our author here uses the words said by Tamar in 
order to prove her righteousness and her unshaken faith, referring to the personal effects of Judah that were in her possession.' ${ }^{22}$

Rabbi Mordechai places in the mouth of the proselyte a clear attack against Christianity. When the proselyte says regarding circumcision, 'I have removed not only the foreskin of my heart, but also the foreskin of the flesh,' this is a protest against the words of Paul in the New Testament. ${ }^{23}$ But the full expression of the inclusion of the proselyte within the people of Israel appears when the liturgical author applies to the proselyte the phrase 'by those close to Me I shall be sanctified' (Leviticus 10:3), the expression used by Moses to comfort his brother Aaron upon the death of his sons. The proselytes are those who are close to God, they are the exemplary Jews. In a second piyyut, R. Moshe ben Yaakov defines Abraham the proselyte in accordance with his faith and his deeds. He is prepared to be burnt alive rather than recant and believe in 'the hanged one'; he cuts himself off from the pagan world when he has himself been circumcised like Abraham. ${ }^{24}$

\section{Notes}

1 J. M. Panitz, 'Conversion to Judaism in the Middle Ages: Historic Patterns and New Scenarios,' Conservative Judaism 36 (1983), No. 4, p. 46; A. Reiner, 'L'attitude envers les proselytes en Allemagne et en France du XIe au XIIIe Siecle,' Revue des études juives 167 (2008), pp. 99-119.

2 b. Yevamot 22a, 48b, 62a, 97b. This expression only appears in the Babylonian Talmud. In the Jerusalem Talmud, there is another expression, 'A Gentile has no father.' The former expression indicates the proselyte's complete break with the connection to his biological past. The second expression expresses doubt regarding familial relationships among Gentiles from the outset, but it is not directly relevant to the present discussion. M. Lavie, "'A Convert is Like a Newborn Child”: The Concept and its Implications in Rabbinic Literature' [Hebrew], PhD Thesis, Ben-Gurion University of the Negev 2003, pp. 49-57.

3 A. Van Gennep, The Rites of Passage, London 1960, pp. 91-92; M. Eliade, Rites and Symbols of Initiation: The Mysteries of Birth and Rebirth, New York 1965, pp. 28-37 and in the introduction.

4 The permission in principle for a mother and son or brother and sister who have converted to marry one another is of course strictly theoretical. The sources stress that this is not a real option, lest it be said that those who convert to Judaism do so in order to commit incest!

5 m. Bikkurim 1.4.

6 A. Linder, Roman Imperial Legislation on the Jews [Hebrew], Jerusalem 1983, pp. 53-57.

7 Rashi in Yebamot 47b s.v. deamar mar, 119b s.v. kashim gerim, Niddah 13b s.v. 
ke-saphat, Sanhedrin 27b s.v. ella be-pashol, 39b s.v. mipnei ma, to Exodus 30:7. Tosafot Niddah 13b s.v. kashim.

8 Tosafot Yebamot 24b s.v. lo bymei David.

9 Rashi in Yebamot 47b. Rashi adds here to that which appears in the Talmud and, in characteristic fashion, states that at the time that the Temple was standing, the convert was also required to bring a sacrifice, and if he did not do so the process of conversion was incomplete. See also Tosafot Yebamot 24b s.v.ולא בימי דויד; Eliezer ben Nathan, Sefer Even haEzer, Sefer Ra'avan, Jerusalem 1984, 242b; and in Moses of Coucy, Semag: Sefer Mizvot Gadol, Jerusalem 1961.

10 Mordechai Yebamot, No. 100. During the fourteenth century R. Yaakov ben Asher (Ba'al ha-Turim), emphasizes that all converts are accepted, notwithstanding ulterior motives_-see Tur, Yoreh De'ah 268.

11 Jacob and Gershom the Circumcisers [Hagozer], Sefer Zikhron Brit, ed. J. Glassberg, Berlin 1892, p. 133.

12 Tosafot Yebamot 109b s.v. raha tahat raha.

13 Tosafot Kiddushin 70b s.v. khashim.

14 Ya’akov ben Meir, Sefer ha-Yashar (Responsa), ed. S. Rosenthal, Berlin 1918, No. 51. See Tosafot Bava Batra 140a; Tosafot Yebamot 47b-48b and 109b, Tosafot Kiddushin 17b and 70b, Tosafot Avodah Zarah 64b; Mordechai Mo'ed Katan, Nos. 907-908. See Reiner, 'L'attitude envers les proselytes,' pp. 99-119.

15 Eliezer ben Joel ha-Levi, Sefer Ra'aviah, ed. V. Aptowizer, 5 vols. Jerusalem 1983, 2008, Vol. 2, Megillah 549.

16 G. Porton, The Stranger Within Your Gates, Chicago 1994, pp. 194-195; M. Lavie, “"A Convert is Like a Newborn Child,"' pp. 103-105; M. Lavee, 'Converting the Missionary Image of Abraham: Rabbinic Traditions Migrating from the Land of Israel to Babylon,' in: Abraham, the Nations, and the Hagarites: Jewish, Christian, and Islamic Perspectives on Kinship with Abraham, eds. M. Goodman, G. van Kooten, and J. van Ruiten, Lieden 2011, pp. 203-222.

17 A. Habermann, ed., Sefer Gezerot Ashkenaz ve-Zarfat, Jerusalem 1945, pp. 49, 35, 103; S. Salfeld, Das Martyrlogium des Nürnberger Memorbuches, Berlin 1938, p. 9.

18 Midrash Bereshit Rabba, Jerusalem 1965, Noah 38:13.

19 Midrash Bereshit Rabba, 39:1, p. 365; MidrashShir ha-Shirim Rabbati, ed. S. Dunski, Jerusalem 1980, Parasha 1; Yalkut Shimoni, Vol. 2, Jerusalem 1980, Shir ha-Shirim No. 981; Abraham bar Azriel, Sefer Arugat ha-Boshem, ed. E. E. Urbach, 3 vols. Jerusalem 1939-63, Vol. 2, p. 122, note 11.

20 Salfeld, Das Martyrlogium des Nürnberger Memorbuches, p. 22; Habermann, ed., Sefer Gezerot Ashkenaz ve-Zarfat, p. 186.

21 I. Davidson, Thesaurus of Medieval Jewish Poetry [Hebrew], 4 vols. New York 1970, Vol. 3, p. 96, No. 604.

22 See Rashi at Genesis 38:25; the phrase 'wear glory' in Ezekiel 24:16 alludes to the tefillin. Actually both Tamar and Abraham were thrown into the burning fire, and both were saved. Tefillin — phylacteries; tallit — prayer shawl. 
23 E.g., Romans 2:25-29; 4:9-12. About the Christian view on circumcision see D. Bell, Sacred Communities, Leiden 2001, pp. 60-69.

24 This poem as well is derived from midrashim which were familiar in the Middle Ages, see Midrash Tanhuma, ed. S. Buber, Jerusalem 1964; Yalkut Shimoni, Vol. 2, Samuel No. 162. 